\title{
Detection of QTLs for Stagonospora glume blotch resistance in Swiss winter wheat
}

\author{
Schnurbusch, T ; Paillard, S ; Fossati, D ; et al
}

\begin{abstract}
Stagonospora nodorum is the causal agent of the Stagonospora glume blotch disease in hexaploid wheat. The Swiss winter bread wheat cv. 'Arina' has a highly effective, durable and quantitative glume blotch resistance. We studied 240 single seed descent (SSD)-derived lines of an 'Arina $\times$ Forno' F5:7 population to identify and map quantitative trait loci (QTLs) for glume blotch resistance under natural infestation. Using composite interval mapping (CIM) and LOD $>4.5$, we detected two chromosomal regions on chromosome arms 3BS and 4BL which were specifically associated with glume blotch resistance. These identified QTLs were designated QSng.sfr-3BS and QSng.sfr-4BL, respectively. QSng.sfr-3BS peaked at the locus Xgwm389 in the telomeric region of the short arm of chromosome 3B and explained $31.2 \%$ of the observed phenotypic variance for the resistance within the population. The responsible QSng.sfr-3BS allele originated from the resistant parent 'Arina'. The QTL QSng.sfr-4BL (19.1\%) mapped to chromosome arm 4BL ('Forno' allele) very close to two known genes, TaMlo and a catalase (Cat). Both QTL alleles combined could enhance the resistance level by about $50 \%$. Additionally, they showed significant epistatic effects (4.4\%). We found PCR-based microsatellite markers closely linked to QSng.sfr-3BS (gwm389) and QSng.sfr-4BL (gwm251) which make marker-assisted selection (MAS) for Stagonospora glume blotch resistance feasible. We also found one resistance QTL, QSng.sfr-5BL, on the long arm of chromosome 5B which overlapped with QTLs for plant height as well as heading time
\end{abstract}

DOI: https://doi.org/10.1007/s00122-003-1372-3

Posted at the Zurich Open Repository and Archive, University of Zurich

ZORA URL: https://doi.org/10.5167/uzh-156547

Journal Article

Published Version

Originally published at:

Schnurbusch, T; Paillard, S; Fossati, D; et al (2003). Detection of QTLs for Stagonospora glume blotch resistance in Swiss winter wheat. TAG. Theoretical and applied genetics. Theoretische und angewandte Genetik, 107(7):1226-1234.

DOI: https://doi.org/10.1007/s00122-003-1372-3 
T. Schnurbusch $\cdot$ S. Paillard $\cdot$ D. Fossati $\cdot$

M. Messmer • G. Schachermayr • M. Winzeler •

B. Keller

\section{Detection of QTLs for Stagonospora glume blotch resistance in Swiss winter wheat}

Received: 3 March 2003 / Accepted: 11 June 2003 / Published online: 19 August 2003

(C) Springer-Verlag 2003

\begin{abstract}
Stagonospora nodorum is the causal agent of the Stagonospora glume blotch disease in hexaploid wheat. The Swiss winter bread wheat cv. 'Arina' has a highly effective, durable and quantitative glume blotch resistance. We studied 240 single seed descent (SSD)derived lines of an 'Arina $\times$ Forno' $\mathrm{F}_{5: 7}$ population to identify and map quantitative trait loci (QTLs) for glume blotch resistance under natural infestation. Using composite interval mapping (CIM) and LOD $>4.5$, we detected two chromosomal regions on chromosome arms $3 \mathrm{BS}$ and 4BL which were specifically associated with glume blotch resistance. These identified QTLs were designated QSng.sfr-3BS and QSng.sfr-4BL, respectively. QSng.sfr$3 B S$ peaked at the locus Xgwm389 in the telomeric region of the short arm of chromosome 3B and explained 31.2\% of the observed phenotypic variance for the resistance within the population. The responsible QSng.sfr-3BS allele originated from the resistant parent 'Arina'. The QTL QSng.sfr-4BL (19.1\%) mapped to chromosome arm 4BL ('Forno' allele) very close to two known genes, TaMlo and a catalase (Cat). Both QTL alleles combined could enhance the resistance level by about $50 \%$. Additionally, they showed significant epistatic effects
\end{abstract}

Communicated by H. C. Becker

T. Schnurbusch · B. Keller $(\bowtie)$

Institute of Plant Biology,

University of Zürich,

Zollikerstrasse 107, 8008 Zürich, Switzerland

e-mail: bkeller@botinst.unizh.ch

S. Paillard · G. Schachermayr · M. Winzeler

Swiss Federal Research Station for Agroecology

and Agriculture (FAL),

Reckenholzstrasse 191, 8046 Zürich, Switzerland

D. Fossati

Swiss Federal Research Station for Plant Production,

Changins, Route de Duillier, P.O. Box 254, 12601 Nyon,

Switzerland

M. Messmer

Pharmaceutical Institute, University of Basel,

Benkenstrasse 254, 4108 Witterswil, Switzerland
(4.4\%). We found PCR-based microsatellite markers closely linked to QSng.sfr-3BS (gwm389) and QSng.sfr4BL (gwm251) which make marker-assisted selection (MAS) for Stagonospora glume blotch resistance feasible. We also found one resistance QTL, QSng.sfr-5BL, on the long arm of chromosome 5B which overlapped with QTLs for plant height as well as heading time.

Keywords Triticum aestivum - QTL · Stagonospora nodorum $\cdot$ Glume blotch · Resistance

\section{Introduction}

The leaf and glume blotch disease of bread wheat (Triticum aestivum L.) is caused by the fungus Phaeosphaeria nodorum (E. Müller) Hedjaroude, anamorph Stagonospora nodorum (Berk.) Castellani and Germano. The disease has recently been renamed according to Cunfer and Ueng (1999). S. nodorum survives on the field debris and is able to infest all above-ground plant organs of wheat. The major primary inoculum are the winddispersed ascospores (sexual form) in late autumn and early spring (Mittelstadt and Fehrmann 1987; Keller et al. 1997a; Bathgate and Loughman 2001). During the growing season, particularly under wet and warm weather conditions, the asexually generated and rain-splashdispersed pycnidiospores successively infect different leaf levels of individual plants (Scharen 1966; Keller et al. 1997a). Wheat kernels are usually infected by the fungus and the infected seeds are possibly contributing to the spread of the fungus over longer distances (Shah and Bergstrom 1993).

S. nodorum is classified as one of the potentially mostdevastating known plant pathogens in agriculture (McDonald and Linde 2002). The high risk potential is based on its mixed reproduction system and its high degree of gene and genotype diversity distributed on a small spatial scale, where almost every lesion on a leaf represents a genetically unique individual (McDonald and Linde 2002). The Stagonospora blotch disease regularly occurs 
in wheat-growing areas across Europe, North Africa, Near East, United States, Australia and Canada (Duczek et al. 1999; Halama 2002).

Genetic variability for Stagonospora blotch resistance is found within the wheat gene pool and its wild relatives (Polley and Thomas 1991; Ma and Hughes 1993; Cunfer and Johnson 1999; Loughman et al. 1999; Wicki et al. 1999). Breeding for Stagonospora blotch resistance is an effective strategy to reduce the yield losses caused by this disease. To-date, there is no evidence for immunity or gene-for-gene interaction in the wheat-S. nodorum pathosystem. Resistance to Stagonospora glume blotch is usually partial (Van der Plank 1963) and generally considered as a quantitative trait. A low correlation between leaf and spike resistance indicated various factors of resistance (Laubscher et al. 1966; Broennimann 1975; Nelson and Gates 1982; Fried and Meister 1987; Bostwick et al. 1993; Van Ginkel and Rajaram 1999; Wicki et al. 1999). As a consequence of the quantitative nature of the disease resistance, selecting resistant genotypes is time-consuming because of the complex interactions between host, pathogen and environment (Van Ginkel and Rajaram 1999). Additionally, plant height and heading time significantly influence the resistance level of $S$. nodorum on the leaf as well as on the spike (Broennimann et al. 1973; Scott et al. 1982; Van Ginkel and Rajaram 1999; Wicki et al. 1999).

Cytogenetic analyses for Stagonospora glume blotch resistance identified 16 chromosomes in the hexaploid wheat genome contributing to resistance in different lines and populations (Kleijer et al. 1977; Walag and Dzieglo 1985, 1987; Auriau et al. 1988; Nicholson et al. 1993; Ma and Hughes 1995; Hu et al. 1996). So far, no QTLs for Stagonospora blotch resistance have been reported. In view of the difficulty to select resistant genotypes against glume blotch, marker-assisted selection (MAS) will be an ideal tool to efficiently introgress resistance QTLs into elite breeding material.

The objective of the present study was to analyze the Stagonospora glume blotch resistance within the Swiss winter wheat population 'Arina $\times$ Forno' under natural infestation, and to identify chromosomal regions which are specifically associated with glume blotch resistance.

\section{Materials and methods}

Plant material

Two hundred and forty single seed descent (SSD)-derived lines $\left(\mathrm{F}_{5.7}\right)$ from the intraspecific cross between the two adapted Swiss winter wheat (T. aestivum L.) cultivars 'Arina' and 'Forno' were evaluated in field trials for their Stagonospora glume blotch reaction. 'Arina' is a tall variety $(1.25 \mathrm{~m})$ with a loose spike. It was released in 1981 and has covered more than $40 \%$ of the wheat acreage of Switzerland since 1985. 'Arina' has maintained its excellent spike resistance against Stagonospora glume blotch in Switzerland and it can therefore be assumed that this resistance is durable. In contrast, 'Forno' is a shorter $(1.05 \mathrm{~m})$ Swiss winter bread-wheat variety highly susceptible to Stagonospora glume blotch under artificial inoculation conditions (Wicki et al. 1999).
Field experiments

Seven field trials were conducted in three locations in 2000 and 2001 representing the diverse wheat growing-areas in Switzerland. Three trials, ZH106 and ZH114 in 2000 as well as ZH109 in 2001, were conducted near Zürich, Switzerland, at the Federal Research Station for Agroecology and Agriculture (FAL-Reckenholz) at 443 $\mathrm{m}$ above sea level on loamy soils with an average precipitation of $1,000 \mathrm{~mm}$ and an average temperature of $7.9^{\circ} \mathrm{C}$. There were two trials (Haag00 and Haag01) in Haag, Canton St. Gallen. Haag is located in the north-eastern part of Switzerland within the river Rhine valley at about $460 \mathrm{~m}$ above sea level. The field experiments were planted on heavy silty clayey soils with an average precipitation of $970 \mathrm{~mm}$ and an average temperature of $8.6^{\circ} \mathrm{C}$. Additionally, in both years there was one trial in Vouvry, Canton Valais, which is located in the south-western part of Switzerland close to Lake Geneva, at the beginning of the Rhone valley. The two field trials (Vouvry00 and Vouvry01) were accomplished on loamy sandy soils at about $381 \mathrm{~m}$ above sea level with an average precipitation of $881 \mathrm{~mm}$ and an average temperature of $8.7^{\circ} \mathrm{C}$.

The lines were grown together with the reciprocal $F_{1}$, three standard cultivars and five replicated entries of the parental lines (267 entries) in a rectangular lattice design with three replications and nine genotypes per incomplete block. Each entry was sown as a one-row plot $(1 \mathrm{~m})$ with approximately 40 to 50 kernels.

\section{Disease phenotyping and trait assessment}

In 2000 and 2001, all field trials were evaluated for natural Stagonospora glume blotch infestation. All standard cultivars, the reciprocal $F_{1}$, the parental lines and the lines of the 'Arina $\times$ Forno' population were phenotyped by estimating visually the average percentage of infected glume area per one-row plot according to the Broennimann scale (Broennimann 1968). The Broennimann scale displays the percentage of the infected glume area per spike starting with $0 \%$ or no visible lesions to $1,5,10,25,50,75$ and up to $100 \%$ infected glume area. In five environments, we scored twice with three replications in the growth stages of the BBCH-scale 71-77 (Meier 2001): ZH106 (26.06. and 30.06.2000), ZH114 (26.06. and 30.06.2000), Haag00 (28.06. and 03.07.2000), Vouvry01 (29.06. and 06.07.2001) and Haag01 (28.06. and 04.07.2001). In Vouvry00 and ZH109, only one late scoring for Stagonospora glume blotch resistance was made (04.07.2000 and 10.07.2001, respectively). Plant height $(\mathrm{cm})$ in all seven environments as well as heading time (days after January 1st) in six environments were investigated with two replications for the 'Arina $\times$ Forno' population.

\section{Genetic linkage map}

Two hundred and forty lines of the 'Arina $\times$ Forno' cross were genotyped with molecular markers. A genetic linkage map based on microsatellite (SSR) and restriction fragment length polymorphism (RFLP) markers was established (Paillard et al. 2003). Three hundred and ninety four loci (186 RFLPs and 208 SSRs) were used on the 'Arina $\times$ Forno' genetic linkage map, and by linkage analysis 380 of these loci mapped to 27 linkage groups with an average marker density of around $8 \mathrm{cM}$ and spanning a total of 3,086 cM. This represents a coverage of approximately $93 \%$ of the ITMI map (Paillard et al. 2003).

\section{Statistical analysis}

\section{Phenotypic data}

Lattice analysis of single environments and analysis of variance across environments were performed with the program PLABSTAT, Version 2M (Utz 1995) on all evaluated traits. The obtained adjusted entry means from single environments were used to compute the analysis of variance (model I) across environments. 
Components of variance were computed considering the effects of the environment and genotype as random. Estimates of variance components $\sigma_{\mathrm{G}}^{2}$ (genetic variance), $\sigma_{\mathrm{E}}^{2}$ (environment variance), $\sigma_{\mathrm{G}}$ $\times \mathrm{E}^{2}$ (genotype $\times$ environment interaction variance) and ${\sigma_{\mathrm{Err}}}^{2}$ (error variance) were calculated. Heritabilities were calculated on an entry mean basis according to Hallauer and Miranda Fo (1981). The distribution of the lines for Stagonospora glume blotch resistance was tested for normality using the SAS univariate procedure (SAS Institute 1991). Phenotypic correlation coefficients of Stagonospora glume blotch scores between the environments were calculated on an entry mean basis. The area under the disease progress curve (AUDPC) was calculated based on two Stagonospora glume blotch scorings per environment (Campbell and Madden 1990; Jeger and Viljanen-Rollinson 2001). Thus, the adjusted entry means for the AUDPC of Stagonospora glume blotch per environment were used to estimate the genotypic value across five environments. The estimation of the genotypic values for heading time as well as plant height are based on adjusted entry means from six and seven environments, respectively.

\section{Genetic mapping and QTL analysis}

For the construction of the genetic linkage map of the 'Arina $x$ Forno' cross, linkage analysis was performed using MAPMAKER 3.0b for MS-DOS (Lander et al. 1987) and assuming Haldane's mapping function (Haldane 1919). For a detailed description see Paillard et al. (2003).

QTL analysis was done for all single markers from the 'Arina $\times$ Forno' map by a simple one-way ANOVA using the SAS glm procedure (SAS Institute 1991). Interval QTL analysis was carried out with the composite interval mapping (CIM) program PLABQTL, Version 1.1 (Utz and Melchinger 2000) which is based on multiple regression. Twenty five markers which were linked closer than $0.2 \mathrm{cM}$ were excluded from the QTL analysis to prevent ill-conditioned equation systems and the generation of "synthetic" new markers by the program. In order to determine the significance of a QTL for simple interval mapping (SIM) and CIM, the critical LOD (logarithm of the odds) thresholds were determined executing a permutation test for each trait with 1,000 permutations. For SIM and CIM, the critical LOD thresholds were set to 2.5 and 4.5, respectively, because the individual critical LOD thresholds at a type I error rate of $\alpha=0.25$ (Beavis 1998) for AUDPC and plant height resulted in 2.27 and 2.38 for SIM, respectively, and 4.43 and 4.56 for CIM, respectively. After calculating SIM for each trait, a whole-genome scan with CIM was conducted using the automatic covariate selection statement ('cov select'). Selected covariates were checked individually for too tight linkage or accumulation close to a detected QTL. A five-fold crossvalidation run was performed with $80 \%$ of the lines used for estimation of the QTLs (positions and effects) and with the remaining $20 \%$ used for validation. In all the interval mapping runs, we used the 'model AA' statement estimating only additive effects due to the small heterozygosity of our population. Detected epistatic effects (digenic QTL $\times$ QTL interactions) were added to the additive effects in the model.

\section{Results}

Stagonospora glume blotch reaction under natural infestation

The AUDPC (Fig. 1A) of the lines across all tested environments was continuously distributed and differed significantly from normality $(p<0.0001)$. The average Stagonospora glume blotch infestation (in the percentage of the infected glume area) across environments was $6.2 \pm 1.7 \%$ for the resistant parent 'Arina' and $19.4 \pm 5.0 \%$ for 'Forno' (Table 1; $\mathrm{LSD}_{5 \%}=6.0$ ). No line exhibited a

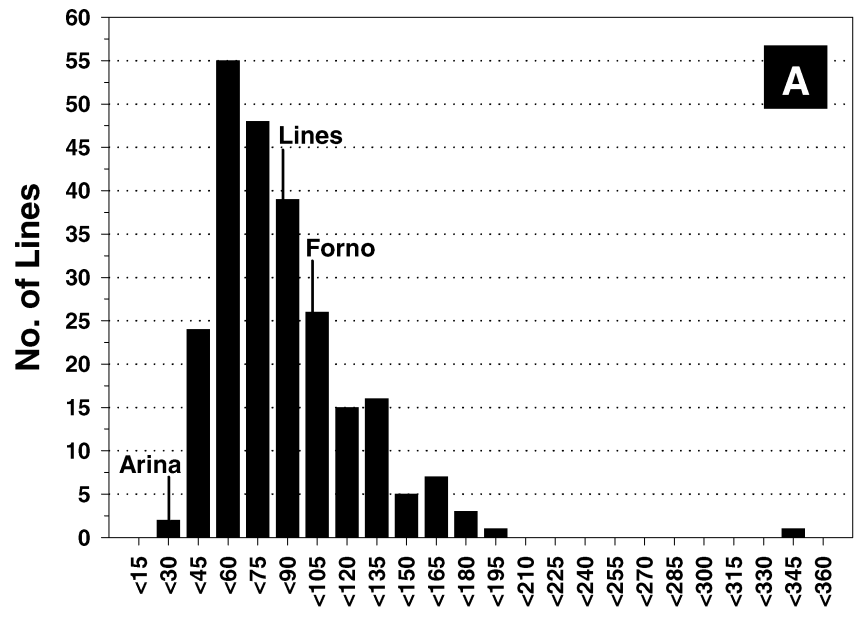

Area under the disease progress curve (AUDPC)

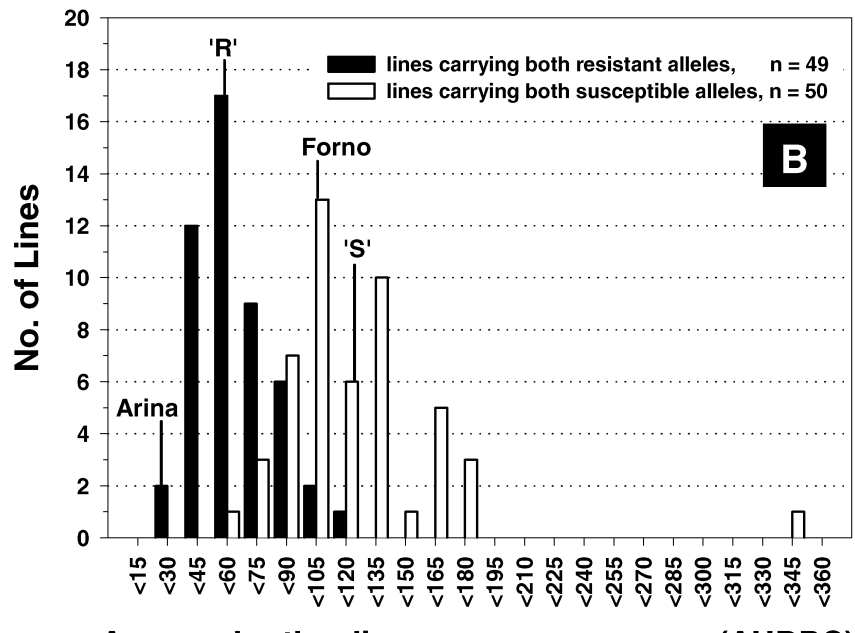

Area under the disease progress curve (AUDPC)

Fig. 1A, B Different frequency distributions of Stagonospora glume blotch susceptibility for the area under the disease progress curve (AUDPC). A Distribution of the average Stagonospora glume blotch susceptibility across five environments in the "Arina $x$ Forno' population. B Phenotypic distribution of lines carrying both resistance alleles (QSng.sfr-3BS plus QSng.sfr-4BL) and their phenotypic average (' $R$ ') compared to the phenotypic average of the susceptible allele combination (' $S$ ')

completely resistant phenotype and there was no line significantly more resistant than 'Arina' $\left(\mathrm{LSD}_{5 \%}=6.0\right)$, whereas transgression for susceptibility occurred frequently (Fig. 1A). Stagonospora glume blotch susceptibility correlated to plant height and heading time with $r=-0.52$ $(p<0.01)$ and $r=-0.10$ (n.s.), respectively. The calculated heritabilities $\left(h^{2}\right)$ for plant height, heading time and AUDPC were 0.97, 0.93 and 0.80 , respectively. The phenotypic correlation coefficients (Spearman) for the AUDPC between all tested environments ranged from 0.59 to $0.84(p<0.01)$ reflecting the relatively high heritability of the trait. The performed ANOVA revealed highly significant $(p<0.01)$ differences of AUDPC among genotypes $(\mathrm{G})$, environments (E) and the $\mathrm{G} \times \mathrm{E}$ interaction as well as 
Table 1 Average natural Stagonospora glume blotch infestation of the parental lines and the 240 phenotyped single seed descent (SSD)-derived lines from the 'Arina $\times$ Forno' cross

\begin{tabular}{|c|c|c|c|c|c|c|}
\hline \multicolumn{2}{|c|}{ Environment } & \multicolumn{5}{|c|}{ Average natural infestation (in \% infected glume area) } \\
\hline & & \multicolumn{2}{|c|}{ Parental lines } & \multicolumn{3}{|c|}{ 'Arina $\times$ Forno' population } \\
\hline & & 'Arina' & 'Forno' & SSD lines & Min & $\operatorname{Max}$ \\
\hline \multirow[t]{3}{*}{2000} & ZH106 & $8.1 \pm 1.1$ & $23.0 \pm 1.0$ & $21.6 \pm 10.0$ & 5.5 & 68.9 \\
\hline & ZH114 & $5.4 \pm 1.6$ & $21.8 \pm 2.1$ & $16.3 \pm 8.6$ & 2.2 & 72.8 \\
\hline & Haag00 & $7.6 \pm 1.3$ & $25.2 \pm 2.1$ & $21.1 \pm 9.1$ & 4.8 & 61.1 \\
\hline \multirow[t]{3}{*}{2001} & Haag01 & $5.5 \pm 1.0$ & $14.6 \pm 1.2$ & $14.6 \pm 8.8$ & 3.6 & 78.9 \\
\hline & Vouvry01 & $3.9 \pm 0.5$ & $12.0 \pm 1.0$ & $11.0 \pm 6.3$ & 3.1 & 74.8 \\
\hline & Average & $6.2 \pm 1.7$ & $19.4 \pm 5.0$ & $15.7 \pm 6.5$ & 6.0 & 52.3 \\
\hline
\end{tabular}

Table 2 Detected QTLs for Stagonospora glume blotch resistance. For each QTL the corresponding marker interval, chromosomal location, individual $R^{2}$ and LOD value is given

\begin{tabular}{|c|c|c|c|c|c|c|c|c|c|c|c|c|c|}
\hline \multirow[t]{3}{*}{ Marker interval } & \multirow[t]{3}{*}{ Chr. } & \multirow{2}{*}{\multicolumn{2}{|c|}{$2000+2001$}} & \multicolumn{6}{|l|}{2000} & \multicolumn{4}{|l|}{2001} \\
\hline & & & & \multicolumn{2}{|c|}{ Haag00 } & \multicolumn{2}{|c|}{ ZH106 } & \multicolumn{2}{|c|}{ ZH114 } & \multicolumn{2}{|c|}{ Haag01 } & \multicolumn{2}{|c|}{ Vouvry01 } \\
\hline & & $\overline{R^{2}}$ & LOD & $\overline{R^{2}}$ & $\frac{\mathrm{LOD}}{}$ & $R^{2}$ & $\frac{\mathrm{LOD}}{}$ & $\overline{R^{2}}$ & LOD & $R^{2}$ & LOD & $R^{2}$ & LOD \\
\hline 1 gwm389-cfd79c & 3BS & 31.2 & 18.0 & 23.0 & 12.6 & - & - & 12.8 & 6.6 & 24.9 & 13.7 & 18.5 & 9.8 \\
\hline 2 gwm165-glk335 & $4 \mathrm{BL}$ & 19.1 & 11.1 & 22.6 & 13.4 & 8.0 & 4.5 & - & - & 20.7 & 12.0 & - & - \\
\hline 3 gwm371-gwm639a & $5 \mathrm{BL}^{\mathrm{PH}}$ b) HT c) & 9.0 & 4.9 & 14.4 & 8.0 & 9.1 & 5.0 & - & - & - & - & - & - \\
\hline 4 glk317a-gwm639b & $5 \mathrm{AL}^{\mathrm{PH}}$ & - & - & - & - & 15.7 & 8.9 & - & - & - & - & - & - \\
\hline 5 cfa2174b-gwm46 & $7 \mathrm{BS}^{\mathrm{PH}}$ & - & - & - & - & 10.5 & 5.8 & - & - & - & - & - & - \\
\hline 6 cfa2134b-gwm131b & $3 \mathrm{BL}^{\mathrm{PH}}$ & - & - & 9.4 & 5.2 & - & - & - & - & - & - & - & - \\
\hline 7 cfd276a-cfa2086 & $2 \mathrm{AL}^{\mathrm{PH}}$ & - & - & - & - & 9.1 & 4.9 & - & - & - & - & - & - \\
\hline \multicolumn{2}{|c|}{ QTL x QTL interaction (\%) } & $1 \times 2$ & $4.4^{* * a}$ & $1 \times 2$ & $4.6^{* *}$ & $2 \times 7$ & $1.9^{* \mathrm{a}}$ & & & $1 \times 2$ & $11.5^{* *}$ & & \\
\hline \multicolumn{2}{|c|}{$\begin{array}{l}\text { Final simultaneous fit for the adjusted } \\
R^{2}(\%) \text { and final LOD }\end{array}$} & 38.9 & 28.8 & 40.5 & 30.2 & 19.4 & 15.8 & 6.2 & 3.8 & 42.0 & 29.5 & 12.4 & 7.3 \\
\hline
\end{tabular}

a $* * * *$ significant digenic QTL by QTL interactions are indicated by $* p<0.05$ and $* * p<0.01$

b PH putative QTL intervals for resistance overlapping with QTL intervals for plant height; see also Table 3

c HT putative QTL intervals for resistance overlapping with QTL intervals for heading time; see also Table 3

a significant difference between the averages of the 2 years $(p<0.1)$. We observed a reduced level of disease severity in 2001 compared to 2000 (Table 1). Vouvry01 yielded the lowest disease severity among all year-locations (Table 1). This was most likely due to the usually early dry weather conditions at this particular location which does not favor fungal spread (Scharen 1966).

\section{QTLs for Stagonospora glume blotch resistance}

In total, we detected seven QTLs for Stagonospora glume blotch resistance using CIM with a LOD threshold of 4.5 (Table 2). In two cases (on chromosome arms 3BS and 4BL), the QTL intervals were not associated with a QTL for a morphological trait such as plant height or heading time. Therefore, these QTLs were considered as resistance loci and designated according to McIntosh et al. (1998) as QSng.sfr-3BS and QSng.sfr-4BL, respectively $($ Sng $=S$. nodorum glume blotch).

The resistance QTLs QSng.sfr-3BS and QSng.sfr-4BL accounted together for $38.9 \%$ (adjusted $R^{2}$ ) of the observed phenotypic variance within the population across all tested environments (Table 2). Comparing the single environments, the individual adjusted $R^{2}$ values ranged from 6.2 to $42.0 \%$. In two environments (ZH114 and Vouvry01), we found one QTL (always QSng.sfr-3BS,
Table 2). By contrast, in ZH106 we detected five QTLs for Stagonospora glume blotch resistance (Table 2). From these five QTLs, only QSng.sfr-4BL was not overlapping with QTL intervals for plant height and/or heading time (Table 2 and Table 3). In Haag00 and Haag01, QSng.sfr$3 B S$ and QSng.sfr-4BL were simultaneously detectable with a LOD larger than 4.5, which resulted in the highest explainable phenotypic variance for resistance compared to the other environments (Table 2; 40.5\% and $42.0 \%$, respectively). In these two environments we also found high epistatic effects between the two QTLs which explained an additional $4.6 \%$ and $11.5 \%$, respectively, of the observed phenotypic variation (Table 2).

The average resistance of the lines carrying the QSng.sfr-3BS allele plus the QSng.sfr- $4 B L$ allele ('R' $=$ average resistant alleles), compared with those lines which did not have any of these alleles (' $\mathrm{S}$ ' = average susceptible alleles), was significantly increased by $50 \%$. For the average resistant allele combination (' $R$ '), we found on average $58.3 \pm 18.8$ for the AUDPC, in comparison to $117.0 \pm 43.8$ for the lines with the susceptible alleles ('S') $\left(\mathrm{LSD}_{5 \%}=45.8\right.$; Fig. 1B).

The most consistent QTL explaining the largest phenotypic variance was QSng.sfr-3BS and it was localized on the telomeric region of the short arm of chromosome 3B, peaking at $\mathrm{Xgwm} 389$ being $0.4 \mathrm{cM}$ distal from the RFLP 
Table 3 Detected QTLs for Stagonospora glume blotch resistance. LOD value, is listed. QTLs for plant height (Ht) and heading time For single environments, each QTL with its corresponding marker interval, peak position, support interval, individual $R^{2}$ as well as

(Eet) are also given

\begin{tabular}{|c|c|c|c|c|c|c|c|}
\hline Chr. & $\begin{array}{l}\text { Detected QTL } \\
\text { (parental allele) }\end{array}$ & Marker interval & $\begin{array}{l}\text { QTL peak } \\
(\mathrm{cM})^{\mathrm{a}}\end{array}$ & $\begin{array}{l}\text { Supp.-interval } \\
(\mathrm{cM})^{\mathrm{b}}\end{array}$ & Environment & $R^{2}(\%)$ & LOD \\
\hline $2 \mathrm{AL}$ & $\begin{array}{l}\text { QSng.sfr-2AL (Arina) } \\
\text { QHt.sfr-2AL (Arina) }\end{array}$ & $\begin{array}{l}\text { cfd276a-cfa2086 } \\
\text { cfd276a-cfa2086 }\end{array}$ & $\begin{array}{l}188 \\
186 \\
186 \\
186 \\
186 \\
188 \\
186 \\
186\end{array}$ & $\begin{array}{l}186-196 \\
174-190 \\
180-190 \\
182-188 \\
180-190 \\
180-192 \\
182-190 \\
180-190\end{array}$ & $\begin{array}{l}\text { ZH106 } \\
\text { Haag01 } \\
\text { Vouvry01 } \\
\text { ZH109 } \\
\text { Haag00 } \\
\text { Vouvry00 } \\
\text { ZH106 } \\
\text { ZH114 }\end{array}$ & $\begin{array}{r}9.1 \\
8.6 \\
26.8 \\
38.7 \\
21.9 \\
12.8 \\
21.9 \\
34.8\end{array}$ & $\begin{array}{r}4.9 \\
4.5 \\
15.7 \\
24.7 \\
12.7 \\
6.9 \\
12.7 \\
21.8\end{array}$ \\
\hline $2 \mathrm{BS} *$ & QSng.sfr-2BS* (Forno $)$ & *OA102-psr933b & $* 0$ & $* 0-6$ & Haag00* & $* 3.6$ & $* 7.0$ \\
\hline $2 \mathrm{BL} *$ & $\begin{array}{l}\text { QSng.sfr- } 2 B L^{*}(\text { Forno }) \\
\text { QHt.sfr-2BL (Forno) }\end{array}$ & $\begin{array}{l}\text { *glk600-psr644b } \\
\text { gwm526b-psr644b }\end{array}$ & $\begin{array}{l}* 158 \\
176 \\
176 \\
176 \\
172 \\
176 \\
* 176\end{array}$ & $\begin{array}{l}* 154-162 \\
170-176 \\
168-176 \\
168-176 \\
164-176 \\
166-176 \\
* 166-176\end{array}$ & $\begin{array}{l}\text { ZH114* } \\
\text { Haag01 } \\
\text { Vouvry01 } \\
\text { Haag00 } \\
\text { Vouvry00 } \\
\text { ZH106 } \\
\text { ZH114* }\end{array}$ & $\begin{array}{l}* 7.8 \\
15.9 \\
22.5 \\
23.8 \\
23.3 \\
14.9 \\
* 13.8\end{array}$ & $\begin{array}{r}* 4.1 \\
4.8 \\
7.2 \\
7.9 \\
7.4 \\
4.7 \\
* 4.3\end{array}$ \\
\hline $3 \mathrm{AS}^{*}$ & QSng.sfr-3AS* (Arina) & $*$ cfd79a-gwm369 & $\begin{array}{l}* 0 \\
* 0\end{array}$ & $\begin{array}{l}* 0-4 \\
* 0-4\end{array}$ & $\begin{array}{l}\text { ZH106* } \\
\text { ZH114* }\end{array}$ & $\begin{array}{l}* 7.1 \\
* 8.3\end{array}$ & $\begin{array}{l}* 3.5 \\
* 4.1\end{array}$ \\
\hline 3BS & QSng.sfr-3BS (Arina) & gwm389-cfd79c & $\begin{array}{l}0 \\
0 \\
0 \\
0\end{array}$ & $\begin{array}{l}0-2 \\
0-2 \\
0-2 \\
0-2\end{array}$ & $\begin{array}{l}\text { Haag01 } \\
\text { Vouvry01 } \\
\text { Haag00 } \\
\text { ZH114 }\end{array}$ & $\begin{array}{l}24.9 \\
18.5 \\
23.0 \\
12.8\end{array}$ & $\begin{array}{r}13.7 \\
9.4 \\
12.6 \\
6.6\end{array}$ \\
\hline $3 \mathrm{BL}$ & $\begin{array}{l}\text { QSng.sfr-3BL (Arina) } \\
\text { QHt.sfr-3BL }(\text { Arina })\end{array}$ & $\begin{array}{l}\text { cfa2134b-gwm131b } \\
\text { cfa2134b-gwm131b }\end{array}$ & $\begin{array}{l}86 \\
78\end{array}$ & $\begin{array}{l}78-96 \\
70-86\end{array}$ & $\begin{array}{l}\text { Haag00 } \\
\text { ZH109 }\end{array}$ & $\begin{array}{l}9.4 \\
8.5\end{array}$ & $\begin{array}{l}5.2 \\
4.6\end{array}$ \\
\hline $4 \mathrm{BL}$ & QSng.sfr-4BL (Forno) & gwm165-glk335 & $\begin{array}{r}14 \\
16 \\
16 \\
* 16 \\
* 16\end{array}$ & $\begin{array}{r}12-16 \\
14-20 \\
14-20 \\
* 14-24 \\
* 14-20\end{array}$ & $\begin{array}{l}\text { Haag01 } \\
\text { Haag00 } \\
\text { ZH106 } \\
\text { Vouvry01* } \\
\text { ZH114* }\end{array}$ & $\begin{array}{r}20.7 \\
22.6 \\
8.0 \\
* 7.5 \\
* 7.0\end{array}$ & $\begin{array}{r}12.0 \\
13.4 \\
4.4 \\
* 4.1 \\
* 3.8\end{array}$ \\
\hline $5 \mathrm{AL}$ & $\begin{array}{l}\text { QSng.sfr-5AL (Arina) } \\
\text { QHt.sfr-5AL (Arina) }\end{array}$ & $\begin{array}{l}\text { glk317a-gwm639b } \\
\text { glk317a-gwm639b }\end{array}$ & $\begin{array}{l}68 \\
70 \\
68 \\
68 \\
68 \\
66\end{array}$ & $\begin{array}{l}62-72 \\
64-74 \\
62-72 \\
64-72 \\
64-72 \\
64-70\end{array}$ & $\begin{array}{l}\text { ZH106 } \\
\text { ZH109 } \\
\text { Haag00 } \\
\text { Vouvry00 } \\
\text { ZH106 } \\
\text { ZH114 }\end{array}$ & $\begin{array}{l}15.7 \\
27.7 \\
15.7 \\
15.4 \\
12.2 \\
24.3\end{array}$ & $\begin{array}{r}8.9 \\
16.5 \\
8.9 \\
8.6 \\
6.7 \\
14.2\end{array}$ \\
\hline $5 \mathrm{BL}$ & $\begin{array}{l}\text { QSng.sfr-5BL (Forno) } \\
\text { QHt.sfr-5BL (Forno) } \\
\text { QEet.sfr-5BL (Forno) }\end{array}$ & $\begin{array}{l}\text { gwm371-gwm639a } \\
\text { gwm371-gwm639a } \\
\text { gwm371-gwm639a }\end{array}$ & $\begin{array}{l}64 \\
58 \\
62 \\
62 \\
62 \\
62 \\
64 \\
62 \\
64 \\
62 \\
64\end{array}$ & $\begin{array}{r}62-64 \\
50-64 \\
* 60-64 \\
60-64 \\
60-64 \\
60-64 \\
60-64 \\
60-64 \\
60-64 \\
60-64 \\
60-64\end{array}$ & $\begin{array}{l}\text { Haag00 } \\
\text { ZH106 } \\
\text { Vouvry01* } \\
\text { Vouvry01 } \\
\text { Haag00 } \\
\text { ZH114 } \\
\text { Vouvry01 } \\
\text { ZH109 } \\
\text { Haag00 } \\
\text { Vouvry00 } \\
\text { ZH106 }\end{array}$ & $\begin{array}{r}14.4 \\
9.1 \\
* 7.5 \\
13.0 \\
9.3 \\
17.0 \\
19.7 \\
9.5 \\
12.9 \\
18.9 \\
19.4\end{array}$ & $\begin{array}{r}8.0 \\
5.0 \\
* 4.1 \\
7.1 \\
5.1 \\
9.6 \\
11.3 \\
5.2 \\
7.1 \\
10.6 \\
10.7\end{array}$ \\
\hline $5 \mathrm{DL} *$ & QSng.sfr-5DL* (Arina) & $* \operatorname{cfd} 81-\mathrm{cfd} 266$ & $* 40$ & $* 26-52$ & Haag00* & $* 7.3$ & $* 4.0$ \\
\hline $6 \mathrm{BL} *$ & $\begin{array}{l}\text { QSng.sfr-6BL* (Arina) } \\
\text { QHt.sfr-6BL* (Arina) }\end{array}$ & $\begin{array}{l}* \text { fba81-psr924 } \\
*_{\text {fba } 81-p s r 924}\end{array}$ & $\begin{array}{l}* 46 \\
* 44\end{array}$ & $\begin{array}{l}* 40-48 \\
* 36-48\end{array}$ & $\begin{array}{l}\text { ZH114* } \\
\text { Vouvry01* }\end{array}$ & $\begin{array}{l}* 6.9 \\
* 7.9\end{array}$ & $\begin{array}{l}* 3.6 \\
* 4.0\end{array}$ \\
\hline $6 \mathrm{Dc}$ & $\begin{array}{l}\text { QSng.sfr-6Dc (Arina) } \\
\text { QHt.sfr-6Dc (Arina) }\end{array}$ & $\begin{array}{l}\text { cfd19-gwm55b } \\
\text { gwm55b-cfd47 }\end{array}$ & $\begin{array}{l}108 \\
120 \\
118 \\
120 \\
120 \\
114 \\
116 \\
116 \\
116\end{array}$ & $\begin{array}{l}102-110 \\
118-120 \\
114-120 \\
118-120 \\
118-120 \\
112-116 \\
114-120 \\
114-118 \\
114-120\end{array}$ & $\begin{array}{l}\text { Haag00 } \\
\text { ZH109 } \\
\text { Haag00 } \\
\text { ZH106 } \\
\text { ZH114 } \\
\text { Vouvry01 } \\
\text { ZH109 } \\
\text { Vouvry00 } \\
\text { ZH106 }\end{array}$ & $\begin{array}{r}9.2 \\
22.0 \\
11.0 \\
19.2 \\
15.9 \\
29.8 \\
12.0 \\
22.1 \\
19.5\end{array}$ & $\begin{array}{r}5.0 \\
11.8 \\
5.6 \\
10.3 \\
8.3 \\
8.3 \\
18.4 \\
6.6 \\
12.5 \\
10.8\end{array}$ \\
\hline 7BS & $\begin{array}{l}\text { QSng.sfr-7BS (Forno) } \\
\text { QHt.sfr-7BS (Forno) }\end{array}$ & $\begin{array}{l}\text { cfa2174b-gwm46 } \\
\text { cfa2174b-gwm46 }\end{array}$ & $\begin{array}{l}26 \\
26 \\
22\end{array}$ & $\begin{array}{l}20-30 \\
20-30 \\
18-28\end{array}$ & $\begin{array}{l}\text { ZH106 } \\
\text { ZH109 } \\
\text { ZH114 }\end{array}$ & $\begin{array}{r}10.5 \\
9.7 \\
9.1\end{array}$ & $\begin{array}{l}5.8 \\
5.2 \\
4.8\end{array}$ \\
\hline
\end{tabular}

${ }^{a}$ Peak of the QTL in cM referring to the chromosome in the A $\times F$ map (Paillard et al. 2003)

b 1-LOD-support-interval providing the approximate QTL position on the chromosome in $\mathrm{cM}$ according to the AxF map (Paillard et al. 2003)

* Putative QTL intervals having a LOD between 3.50 and 4.50 are marked with an asterisk 
marker bcd907b (Fig. 2A). The resistant QSng.sfr-3BS allele originated from the resistant parent 'Arina' and was significant in four environments ranging in $R^{2}$ values from $12.8 \%$ to $24.9 \%$ (Table 2). Across environments, QSng.sfr$3 B S$ was found with a LOD of 18.0 and accounted for $31.2 \%$ of the phenotypic variance for Stagonospora glume blotch resistance (Table 2).

The most probable map position for QSng.sfr- $4 B L$ peaked $1.1 \mathrm{cM}$ distal from the SSR marker gwm251 and $0.8 \mathrm{cM}$ distal to the RFLP marker psr914b (Fig. 2B). QSng.sfr-4BL was detected in all environments with a LOD $>3.5$ with $R^{2}$ values ranging from 7.0 to $22.6 \%$, respectively (Table 3 ). With a LOD $>4.5$, it was still found in three environments (Haag00, ZH106 and Haag01; Table 2). Across environments, this QTL was detected with a LOD of 11.1 and explained $19.1 \%$ of the phenotypic variance for Stagonospora glume blotch resistance (Table 2). The resistant QSng.sfr-4BL allele was derived from the susceptible parent 'Forno'.

The weakest detected QTL explaining the lowest phenotypic variance across all tested environments was QSng.sfr-5BL ( $R^{2} 9.0 \%$ and LOD 4.9; Table 2). It was localized on the long arm of chromosome $5 \mathrm{~B}$ peaking between Xcfd7b and Xgwm639a (Fig. 2C). The QSng.sfr$5 B L$ allele was derived from the susceptible parent 'Forno' and was found in three environments with a LOD $>3.5$ ranging from $7.5 \%$ to $14.4 \%$ for the $R^{2}$ value (Supplementary table). With a LOD $>4.5$, this QTL was detected only in two environments (Haag00 and ZH106; Table 2). Across all environments, QSng.sfr-5BL was the only detected Stagonospora glume blotch resistance QTL associated with plant height as well as heading time (Fig. 2C). The explained phenotypic variance for QHt.sfr-5BL and QEet.sfr-5BL was $11.2 \%$ and $11.5 \%$, respectively.

Cross validation for the AUDPC

In the five-fold cross validation run (CIM, LOD>4.5) QSng.sfr-3BS and QSng.sfr-4BL were always detected, whereas $Q S n g . s f r-5 B L$ only occurred once in split number 2 (Table 4). A similar situation was found for the 100-fold cross validation (CIM, LOD>4.5). QSng.sfr-3BS and QSng.sfr-4BL occurred in all 100 splits but with QSng.sfr-5BL only in 35 cases (data not shown). The mean phenotypic values $\left(R^{2}\right.$ in $\left.\%\right)$ for the five-fold and 100 -fold cross validation did not differ greatly for the calibration (192 lines) with 33.8 and 35.6, respectively, and for the validation (48 lines) with 37.1 and 31.5, respectively (Table 4$)$.

\section{Discussion}

Stagonospora glume blotch resistance is quantitatively inherited

It was known from field trials with artificial inoculations of $S$. nodorum that the two Swiss winter bread wheat
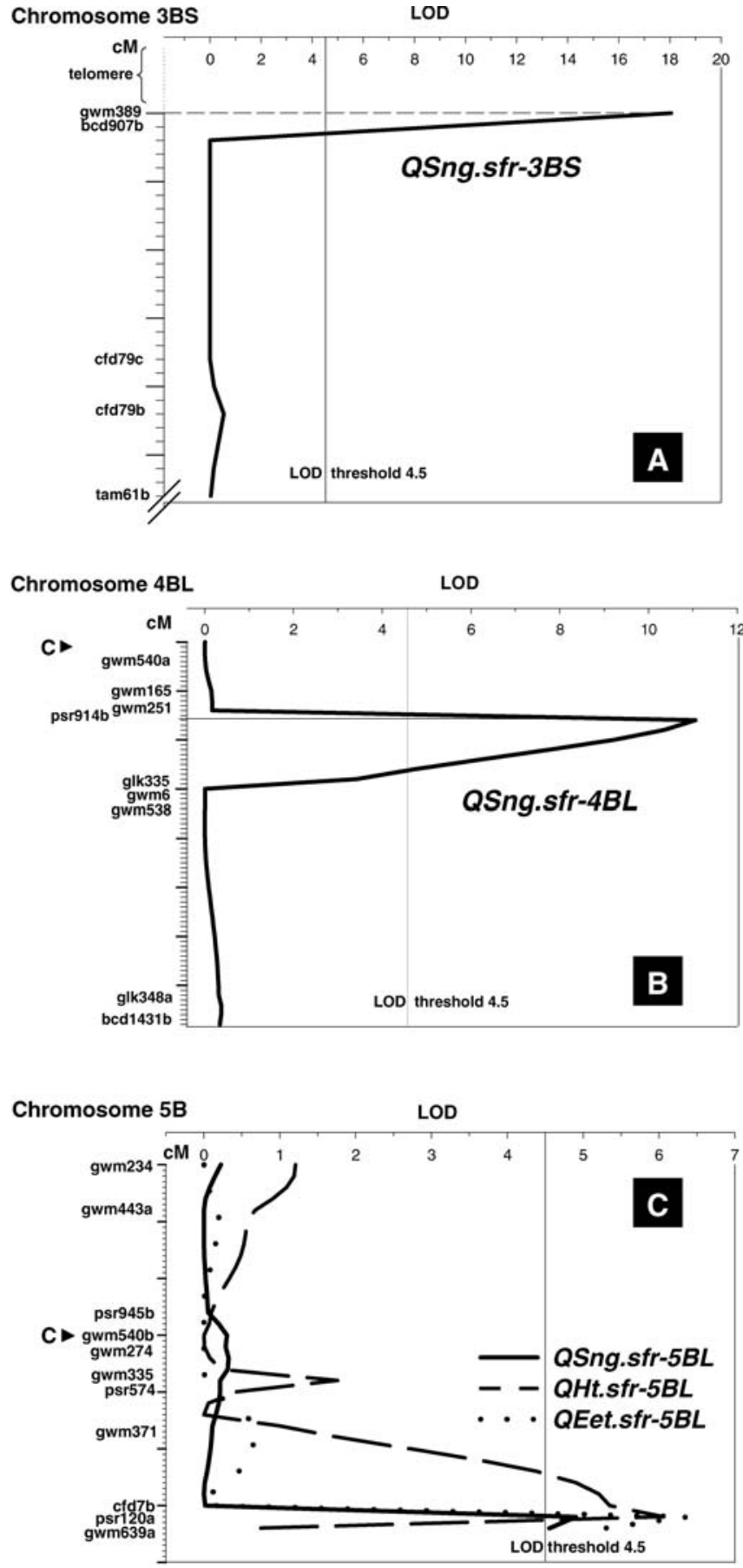

Fig. 2A-C Composite interval analysis of QTLs for the AUDPC on various linkage groups. Linkage groups corresponding to chromosome arms 3BS (A), 4BL (B) and 5B (C). LOD curves were calculated with CIM, LOD>4.5. Each dash on the cM scale represents one $\mathrm{cM}$. The estimated centromere position is indicated by a black arrow

varieties 'Arina' and 'Forno' differ significantly in their level of resistance (Wicki et al. 1999). This difference was also observed in field trials with our segregating population. The relatively low disease score for 'Forno' and the low average score for the lines reflect the 
Table 4 Five-fold cross validation (CV) of QTLs for the AUDPC across all environments

\begin{tabular}{|c|c|c|c|c|}
\hline \multirow{2}{*}{$\begin{array}{l}\text { Cross validation } \\
\text { split }(\mathrm{CV})\end{array}$} & \multicolumn{3}{|c|}{ Calibration for AUDPC (192 lines) } & \multirow{2}{*}{$\begin{array}{l}\text { Validation for AUDPC (48 lines) } \\
\text { adjusted phenotypic variance } \\
\text { explained (\%) }\end{array}$} \\
\hline & Detected QTLs & LOD & $\begin{array}{l}\text { Adjusted } \\
R^{2}(\%)\end{array}$ & \\
\hline 1. & 3BS 4BL & 16.2 & 30.3 & 45.2 \\
\hline 2. & 3BS 4BL 5BL & 21.0 & 36.5 & 35.6 \\
\hline 3. & $3 \mathrm{BS} 4 \mathrm{BL}$ & 21.1 & 38.1 & 25.0 \\
\hline 4. & $3 \mathrm{BS} 4 \mathrm{BL}$ & 16.2 & 30.4 & 44.8 \\
\hline 5. & $3 \mathrm{BS} 4 \mathrm{BL}$ & 18.1 & 33.5 & 34.8 \\
\hline \multicolumn{3}{|c|}{ 5-fold CV: mean phenotypic $R^{2}$ : } & 33.8 & 37.1 \\
\hline \multicolumn{3}{|c|}{100 -fold CV: mean phenotypic $R^{2}$ : } & 35.6 & 31.5 \\
\hline
\end{tabular}

moderate disease pressure under natural conditions. Nevertheless, we found high correlations between environments and high heritabilities (see Results). This clearly reflects that the evaluation of phenotype and experimental design were appropriate.

In our population we observed a continuous phenotypic distribution for Stagonospora glume blotch reaction, confirming its quantitative nature involved in an oligo- or polygenic inheritance pattern. None of the lines showed a completely resistant phenotype and alleles from the susceptible parent also contributed to the resistance. These findings confirm several other genetic studies for resistance against this spike disease (Fried and Meister 1987; Bostwick et al. 1993; Wicki et al. 1999).

Chromosomal regions associated

with glume blotch resistance

We found two QTLs, QSng.sfr-3BS and QSng.sfr-4BL, for Stagonospora glume blotch resistance which were not associated with plant height or heading time.

The most consistent QTL explaining the largest phenotypic variance $\left(R^{2}=31.2 \%\right)$ was $Q S n g . s f r-3 B S$ which was found in four out of five environments. For this reason, we consider QSng.sfr-3BS to be a major resistance QTL for Stagonospora glume blotch. Chromosome arm 3BS has not yet been reported to contribute to glume blotch resistance, although the 3BL arm was shown to affect flag leaf and spike resistance to $S$. nodorum (Hu et al. 1996). Moreover, chromosome 3B conferred seedling resistance against Stagonospora leaf blotch (Nicholson et al. 1993). QSng.sfr-3BS was localized in a highly interesting chromosomal region peaking at Xgwm389 on chromosome arm 3BS. Recently, a major Fusarium head blight (FHB) QTL (QFhs.ndsu-3B) from wheat was mapped in different genetic backgrounds at about $8 \mathrm{cM}$ proximal to $\mathrm{Xgwm} 389$ within the marker interval gwm533-barc147 (Anderson et al. 2001; Zhou et al. 2002). After CIM analyses in our population, QSng.sfr-3BS peaked at Xgwm389 supporting the hypothesis that it is probably distal to $Q F h$ s.ndsu- $3 B$.

QSng.sfr-4BL shows that the susceptible variety 'Forno' also contributed to glume blotch resistance. Combined with QSng.sfr-3BS, these two QTLs reduced glume blotch susceptibility in our population by about
$50 \%$. This is in agreement with the observation that the combination of a few genes may be sufficient to confer partial resistance to the Stagonospora blotch disease in wheat (Van Ginkel and Rajaram 1999).

QSng.sfr-4BL was localized on the long arm of chromosome 4B. So far, there were no indications for chromosome 4BL to be involved in Stagonospora blotch resistance in wheat at all, neither for the leaf nor for the spike. Only $5 \mathrm{cM}$ distal from Xpsr914 a catalase gene, designated as Xpsr484(Cat)-4B, mapped in the consensus map of hexaploid wheat (Gale et al. 1995). Catalases are activated during abiotic or biotic stress responses in plants. They belong to one of the major reactive oxygen species (ROS)-scavenging mechanisms in plant cells which are localized in the peroxisomes and their primary ROS is hydrogen peroxide $\left(\mathrm{H}_{2} \mathrm{O}_{2}\right)$ (Willekens et al. 1997; Mittler 2002). Another candidate gene for QSng.sfr-4BL adjacent to Xpsr484(Cat)-4B is TaMlo, the wheat ortholog of the Mlo gene in barley. The presence of the $M L O$ protein provides cell death protection in responses to biotic and abiotic stresses (Piffanelli et al. 2002). Mlo maps to the long arm of chromosome $4 \mathrm{H} 2.9 \mathrm{cM}$ distal to the catalase, Cat2, gene (Skadsen et al. 1995). In wheat, TaMlo was recently mapped $1.2 \mathrm{cM}$ distal to Xcdo1312$4 B L$ (Elliott et al. 2002). In the ITMI population, it mapped approximately $3 \mathrm{cM}$ proximal to Xgwm251-4BL, and QSng.sfr- $4 B L$ peaked $1.9 \mathrm{cM}$ distal to Xgwm251-4BL in our cross. Further high-resolution mapping is required to test whether QSng.sfr-4BL maps to Xpsr484(Cat)-4B or TaMlo.

QTLs for plant height often coincide with QTLs for glume blotch resistance

One out of three detected QTLs for Stagonospora glume blotch resistance, $Q S n g . s f r-5 B L$, across all environments simultaneously, overlapped with a QTL for plant height $(Q H t . s f r-5 B L)$ as well as a QTL for heading time (QEet.sfr-5BL).

Resistance to Stagonospora leaf and glume blotch is genetically tightly linked or pleiotropic to plant height and heading time (Scott et al. 1982; Wicki et al. 1999). In other host-pathogen interactions such as FHB in barley, it was found that QTLs for morphological characters like plant height or heading time influenced resistance and 
resulted in overlapping QTL intervals for FHB resistance (Zhu et al. 1999; Ma et al. 2000). We found a high negative phenotypic correlation between plant height and glume blotch susceptibility under natural infection. This correlation is in agreement with the natural epidemiology of $S$. nodorum, as the natural history of disease initially starts from field debris on the ground. Then, during the growing season the fungus successively infests all aboveground plant organs, including glumes as a last resort. Under such conditions, taller plants would have an advantage because their glumes are higher and not easy for the fungus to reach. In this respect, tallness functions as a sort of escape resistance to the fungus. For QSng.sfr$5 B L$, we can conclude that heading time is most likely not affecting resistance due to the low phenotypic correlation. Thus, the resistance effect of QSng.sfr-5BL is probably closely linked or pleiotropic to plant height because both LOD-curves peak at the same map location.

\section{Environmental influence}

on Stagonospora glume blotch resistance

From population genetic studies, S. nodorum exhibited a high genetic similarity among natural populations from different geographical origins, suggesting widespread gene flow and the absence of pathogen adaptation to specific wheat varieties (Keller et al. 1997a, b). Thus, the observed environmental differences for Stagonospora glume blotch resistance in our population should not result from pathogen races. In fact, the differences might have occurred from uncontrolled infection conditions under natural infestation. Some environments seemed to favor the association of morphological traits such as plant height and resistance (ZH106) and, therefore, these locations are less valuable in breeding programs. In contrast, the results from both years in Haag confirmed the observation that this particular location is very favorable to select for Stagonospora blotch resistance (Broennimann 1968). Despite these problems, the obtained genotypic values across all environments allowed the detection of three QTLs for Stagonospora glume blotch resistance. These findings were confirmed by the five-fold and 100-fold cross-validation runs which analyzed the influence of genotypic and environmental sampling, and also determined the bias and sampling error of the explained variance. Based on these results, we conclude that at least $30 \%$ of the observed phenotypic variance within the population could be explained by the detected resistance QTLs.

\section{Outlook}

Considering the labor of selecting for glume blotch resistance in adult plants, we think that MAS will be an excellent tool for breeders to introduce identified major resistance QTLs into elite short-straw breeding material to enhance the level of partial resistance against $S$. nodorum.
As we could identify closely linked molecular markers for two major resistance QTLs, MAS for Stagonospora glume blotch resistance seems to be feasible. Moreover, mapping of additional markers will result in a better genetic resolution and more tightly linked markers for QSng.sfr$3 B S$ and QSng.sfr-4BL. Successful MAS and cloning of the major resistance QTL QSng.sfr-3BS will crucially depend on the generation of new flanking markers on chromosome 3BS.

Acknowledgements We thank B. Senger and P. Streckeisen for their excellent technical assistance, and R. Enderlin for conducting the field trials in Haag, Canton St. Gallen, Switzerland. We are grateful to Prof. Dr. H.F. Utz for providing the computer packages PLABSTAT and PLABQTL. This work was supported by the University of Zürich. The authors declare that the experiments conducted for this publication comply with the current laws of Switzerland.

\section{References}

Anderson JA, Stack RW, Liu S, Waldron BL, Fjeld AD, Coyne C, Moreno-Sevilla B, Fetch JM, Song QJ, Cregan PB, Frohberg RC (2001) DNA markers for Fusarium head blight resistance QTLs in two wheat populations. Theor Appl Genet 102:11641168

Auriau P, Rapilly F, Cauderon Y (1988) Monosomic analysis of resistance to Septoria nodorum Berk. in soft red wheat [Triticum aestivum L. em Thell (Vill) M.K.]. Agronomie 8:71-77

Bathgate JA, Loughman R (2001) Ascospores are a source of inoculum of Phaeosphaeria nodorum, $P$. avenaria f. sp. avenaria and Mycosphaerella graminicola in Western Australia. Aust Plant Pathol 30:317-322

Beavis WD (1998) QTL analyses: power, precision, and accuracy. In: Paterson $\mathrm{AH}$ (ed) Molecular dissection of complex traits. CRC Press, Boca Raton, New York, pp 145-162

Bostwick DE, Ohm HW, Shaner G (1993) Inheritance of Septoria glume blotch resistance in wheat. Crop Sci 33:439-443

Broennimann A (1968) Untersuchungen über Septoria nodorum Berk. des Weizens. Mitteil Schweiz Landw 16:65-76

Broennimann A (1975) Contributions to genetics of tolerance towards Septoria nodorum Berk. in wheat (Triticum aestivum L.). J Plant Breed 75:138-160

Broennimann A, Fossati A, Hani F (1973) Spreading of Septoria nodorum Berk. and damage to artificially induced mutants of winter wheat cultivar Zenith (Triticum aestivum L.). J Plant Breed 70:230-245

Campbell CL, Madden LV (1990) Introduction to plant disease epidemiology. John Wiley and Sons, New York, USA

Cunfer BM, Johnson JW (1999) Soft red winter wheat with resistance to Stagonospora nodorum and other foliar pathogens. In: van Ginkel M, McNab A, Krupinsky JM (eds) Septoria and Stagonospora diseases of cereals: a compilation of global research. CIMMYT, Mexico, D.F., pp 159

Cunfer BM, Ueng PP (1999) Taxonomy and identification of Septoria and Stagonospora species on small-grain cereals. Annu Rev Phytopathol 37:267-284

Duczek LJ, Sutherland KA, Reed SL, Bailey KL, Lanford GP (1999) Survival of leaf spot pathogens on crop residues of wheat and barley in Saskatchewan. Can J Plant Pathol 21:165173

Elliott C, Zhou FS, Spielmeyer W, Panstruga R, Schulze-Lefert P (2002) Functional conservation of wheat and rice Mlo orthologs in defense modulation to the powdery mildew fungus. Mol Plant-Microbe Interact 15:1069-1077 
Fried PM, Meister E (1987) Inheritance of leaf and head resistance of winter wheat to Septoria nodorum in a diallel cross. Phytopathology 77:1371-1375

Gale MD, Atkinson MD, Chinoy CN, Harcourt RL, Jia J, Li QY, Devos KM (1995) Genetic maps of hexaploid wheat. Proc 8th Int Wheat Genetics Symposium, China Agricultural Scientech Press, Beijing, China, pp 29-40

Halama P (2002) Mating relationships between isolates of Phaeosphaeria nodorum, (anamorph Stagonospora nodorum) from geographical locations. Eur J Plant Pathol 108:593-596

Haldane JBS (1919) The combination of linkage values, and the calculation of distances between loci of linked factors. J Genet 8:299-309

Hallauer AR, Miranda Fo JB (1981) Quantitative genetics in maize breeding. The Iowa University Press, Ames, Iowa, USA

Hu XY, Bostwick D, Sharma H, Ohm H, Shaner G (1996) Chromosome and chromosomal arm locations of genes for resistance to Septoria glume blotch in wheat cultivar Cotipora. Euphytica 91:251-257

Jeger MJ, Viljanen-Rollinson SLH (2001) The use of the area under the disease progress curve (AUDPC) to assess quantitative disease resistance in crop cultivars. Theor Appl Genet 102:3240

Keller SM, McDermott JM, Pettway RE, Wolfe MS, McDonald BA (1997a) Gene flow and sexual reproduction in the wheat glume blotch pathogen Phaeosphaeria nodorum (Anamorph Stagonospora nodorum). Phytopathology 87:353-358

Keller SM, Wolfe MS, McDermott JM, McDonald BA (1997b) High genetic similarity among populations of Phaeosphaeria nodorum across wheat cultivars and regions in Switzerland. Phytopathology 87:1134-1139

Kleijer G, Bronnimann A, Fossati A (1977) Chromosomal location of a dominant gene for resistance at seedling stage to Septoria nodorum Berk. in wheat variety Atlas66. J Plant Breed 78:170173

Lander ES, Green P, Abrahamson J, Barlow A, Daley MJ, Lincoln SE, Newburg L (1987) MAPMAKER: an interactive computer package for constructing primary genetic linkage maps of experimental and natural populations. Genomics 1:174-181

Laubscher FX, von Wechmar B, von Schalkwyk D (1966) Heritable resistance of wheat varieties to glume blotch (Septoria nodorum Berk.). Phytopathology Z 56:260-264

Loughman R, Wilson RE, Goss IM, Foster DT, Murphy NEA (1999) Varieties and advanced lines resistant to Septoria diseases of wheat in Western Australia. In: van Ginkel M, McNab A, Krupinsky JM (eds) Septoria and Stagonospora diseases of cereals: a compilation of global research. CIMMYT, Mexico, D.F., pp 145-148

Ma H, Hughes GR (1993) Resistance to Septoria nodorum blotch in several Triticum species. Euphytica 70:151-157

Ma H, Hughes GR (1995) Genetic control and chromosomal location of Triticum timopheevii-derived resistance to Septoria nodorum blotch in durum wheat. Genome 38:332-338

Ma ZP, Steffenson BJ, Prom LK, Lapitan NLV (2000) Mapping of quantitative trait loci for Fusarium head blight resistance in barley. Phytopathology 90:1079-1088

McDonald BA, Linde C (2002) Pathogen population genetics, evolutionary potential, and durable resistance. Annu Rev Phytopathol 40:349-379

McIntosh RA, Hart GE, Devos KM, Gale MD, Rogers WJ (1998) Catalogue of gene symbols for wheat. Proc 9th Int Wheat Genetics Symposium, Saskatoon, Saskatchewan, University Extension Press, University of Saskatchewan, vol 5

Meier U (2001) Growth stages of mono- and dicotyledonous plants. 2nd, Federal Biological Research Centre for Agriculture and Forestry (BBA), Braunschweig, Germany

Mittelstadt A, Fehrmann H (1987) The occurrence of the perfect stage of Septoria nodorum in the Federal Republic of Germany. J Plant Dis Protect 94:380-385

Mittler R (2002) Oxidative stress, antioxidants and stress tolerance. Trends Plant Sci 7:405-410
Nelson LR, Gates CE (1982) Genetics of host plant resistance of wheat to Septoria nodorum. Crop Sci 22:771-773

Nicholson P, Rezanoor HN, Worland AJ (1993) Chromosomal location of resistance to Septoria nodorum in a synthetic hexaploid wheat determined by the study of chromosomal substitution lines in Chinese Spring wheat. Plant Breed 110:177-184

Paillard S, Schnurbusch T, Abderhalden O, Messmer M, Sourdille P, Winzeler M, Keller B, Schachermayr G (2003) An integrative genetic linkage map of winter wheat (Triticum aestivum L.). Theor Appl Genet (in press)

Piffanelli P, Zhou FS, Casais C, Orme J, Jarosch B, Schaffrath U, Collins NC, Panstruga R, Schulze-Lefert P (2002) The barley $M L O$ modulator of defense and cell death is responsive to biotic and abiotic stress stimuli. Plant Physiol 129:1076-1085

Polley RW, Thomas MR (1991) Surveys of diseases of winter wheat in England and Wales, 1976 to 1988. Ann Appl Biol 119:1-20

SAS Institute (1991) SAS language and procedures: usage 2, version 6, first edition. SAS Institute Inc, Cary, N.C., USA

Scharen AL (1966) Cyclic production of pycnidia and spores in dead wheat tissue by Septoria nodorum. Phytopathology 56:580

Scott PR, Benedikz PW, Cox CJ (1982) A genetic study of the relationship between height, time of ear emergence and resistance to Septoria nodorum in wheat. Plant Pathol 31:45-60

Shah D, Bergstrom GC (1993) Assessment of seed-borne Stagonospora nodorum in New York soft white winter wheat. Plant Dis 77:468-471

Skadsen RW, Schulze-Lefert P, Herbst JM (1995) Molecular cloning, characterization and expression analysis of two catalase isozyme genes in barley. Plant Mol Biol 29:1005-1014

Utz HF (1995) PLABSTAT - a computer program for statistical analysis of plant breeding experiments. Version 2.0M. Institute of Plant Breeding, Seed Science and Population Genetics, University of Hohenheim, Stuttgart, Germany

Utz HF, Melchinger AE (2000) PLABQTL: a computer program to map QTL. Version 1.1. Institute of Plant Breeding, Seed Science, and Population Genetics, University of Hohenheim, Stuttgart, Germany

Van der Plank JE (1963) Plant diseases: epidemics and control. Academic Press, New York, USA

Van Ginkel M, Rajaram S (1999) Breeding for resistance to the Septoria/Stagonospora blights of wheat. In: van Ginkel M, McNab A, Krupinsky JM (eds) Septoria and Stagonospora diseases of cereals: a compilation of global research. CIMMYT, Mexico, D.F., pp 117-126

Walag H, Dzieglo A (1985) Monosomic location of genes for resistance to Septoria nodorum (Berk.) in the spring wheat (Triticum aestivum L.) variety Sappo. Hodowla Roslin Aklimatyzacja I Nasiennictwo 29:11-19

Walag H, Dzieglo A (1987) Location of resistance genes to Septoria nodorum (Berk.) of summer wheat of the Weibull 15440 variety (Triticum aestivum L.). Hodowla Roslin Aklimatyzacja I Nasiennictwo 31:1-6

Wicki W, Winzeler M, Schmid JE, Stamp P, Messmer M (1999) Inheritance of resistance to leaf and glume blotch caused by Septoria nodorum Berk. in winter wheat. Theor Appl Genet 99:1265-1272

Willekens H, Chamnongpol S, Davey M, Schraudner M, Langebartels C, VanMontagu M, Inze D, VanCamp W (1997) Catalase is a sink for $\mathrm{H}_{2} \mathrm{O}_{2}$ and is indispensable for stress defence in C-3 plants. Embo J 16:4806-4816

Zhou WC, Kolb FL, Bai GH, Shaner G, Domier LL (2002) Genetic analysis of scab resistance QTLs in wheat with microsatellite and AFLP markers. Genome 45:719-727

Zhu H, Gilchrist L, Hayes P, Kleinhofs A, Kudrna D, Liu Z, Prom L, Steffenson B, Toojinda T, Vivar H (1999) Does function follow form? Principal QTLs for Fusarium head blight (FHB) resistance are coincident with QTLs for inflorescence traits and plant height in a doubled-haploid population of barley. Theor Appl Genet 99:1221-1232 